\title{
ASSOCIATION OF HELICOBACTER PYLORI RESTRICTION ENDONUCLEASE-REPLACING GENE, hrgA WITH OVERT GASTROINTESTINAL DISEASES
}

\author{
Manoj $\mathbf{G}^{1}$, Santosh K. TIWARI ${ }^{1}$, Vishwas SHARMA ${ }^{1}$, Mohammed Aejaz HABEEB ${ }^{1,2}$, \\ Aleem A. KHAN ${ }^{1}$ and Habibullah $\mathbf{C M}^{1}$
}

\begin{abstract}
Background and Aim - Helicobacter pylori has been proven to be responsible for causing various gastrointestinal disorders including gastric adenocarcinoma. Several genes of pathogen (the genes of the cag-PAI, vacA, iceA, and babA) either in combination or independently have been reported to significantly increase the risk of ulceration/gastric carcinoma, with the cagA gene having the strongest predictive value. Pursuit to identify new genes which could serve as a marker of overt disease progression, lead to the discovery of $h r g \mathrm{~A}$ gene. Methods - Fifty-six indigenous strains of $H$. pylori from subjects with various gastric disorder were screened to assess the status of $h r g A$ gene along with the cagA gene using simple polymerase chain reaction using specific oligonucleotide primers. Post-amplification, amplicons were subjected for sequencing to identify any strain specific variations in sequences from the H. pylori isolated from different disease manifestations. Histopathological analysis was done to ascertain any significant change in the histological scores of subjects infected with $\operatorname{cag} \mathrm{A}+/ h r g \mathrm{~A}+$ and cagA-/hrg+ strains. Results - All the $56(100 \%)$ subjects amplified with the oligonucleotide primers specific to $h r g \mathrm{~A}$ gene, whereas $81.71 \%$ subjects showed the presence of $\operatorname{cagA}$ gene. Sequencing of the amplimers showed $99 \%$ homology. Histology of the $\operatorname{cagA}+/ \mathrm{hrgA}+$ and $\operatorname{cagA}-/$ hrg+ subjects did not show any significant difference. Conclusion - hrgA gene of Helicobacter pylori is not a ideal surrogate marker for identifying individuals with higher risk of developing overt gastro-duodenal diseases such as neoplasia of the stomach.
\end{abstract}

HEADINGS - Helicobacter pylori. Stomach neoplasms. Adenocarcinoma. Bacterial proteins. Polymerase chain reaction.

\section{INTRODUCTION}

Adenocarcinoma of the stomach is one of the leading causes of cancer related deaths in the world ${ }^{(9)}$. Although the incidence of gastric cancer has declined much significantly in the West, it still remains a major type of neoplasm especially in the East Asian countries like Japan, China, and Korea ${ }^{(14)}$. Development of gastric cancer is believed to be a multi-factorial event and probably takes 3 to 4 decades to manifest. With the primary etiological agents being exposure to chemical carcinogens, Helicobacter pylori occupies a unique niche in the genesis of gastric cancer. In addition, epidemiological studies have indicated that infection with Helicobacter pylori is considered a major risk factor for gastric cancer ${ }^{(11)}$, and the $\mathrm{WHO} /$ IARC $^{(4)}$ has classified this bacterium as a definite biological carcinogen in 1994. Though it is hypothesized that the development of cancer depends on a series of complex molecular interaction between the host and bacteria ${ }^{(4,}$ ${ }^{10,11)}$, the precise patho-mechanisms linking $H$. pylori infection and gastric carcinogenesis still remains an unsolved enigma.
The predisposition among H. pylori infected individuals to develop various gastro-duodenal diseases viz duodenal ulcer (DU), gastric ulcer, gastric carcinoma and MALT-lymphoma mainly depends upon the bacterial and host factors and in part on the topography of the gastric inflammation ${ }^{(5,6,10)}$. Studies have identified several strain specific factors that potentially are markers for the differential risk associated with $H$. pylori colonization ${ }^{(2,}$ 15); at present, the genes of the cag pathogenicity island (cag-PAI) and vacA, SADAKANE et al. ${ }^{(12)}$; MAEDA et al..$^{(7)}$; TIWARI et al. ${ }^{(13)}$ have been reported to possess strongest predictive values. However, most strains isolated from Indian sub-continent and other East Asian countries possess these determinants irrespective of their clinical outcome. Thus, identification of specific bacterial factors that can serve as surrogate marker for the progression to ulceration or to gastric cancer remains desirable.

ANDO et al. (1), in 2002, while working with restrictionmodification (R-M) systems, discovered potential marker Helicobacter pylori restriction endonuclease-replacing gene ( $h r g \mathrm{~A})$ that in conjunction with cagA identified individuals associated with gastric cancer. The same

${ }^{1}$ Center for Liver Research and Diagnostics; '2Dept. of Gastroenterology and Hepatology Deccan College of Medical Sciences, Kanchanbagh, Hyderabad 500 058, Andhra Pradesh, India

Correspondence: Dr. Aleem A. Khan - Scientist and Head - Center for Liver Research and Diagnostics, Deccan College of Medical Sciences and Allied Hospitals Kanchanbagh, Hyderabad 500 058, Andhra Pradesh, India. Email: aleem_a_khan@rediffmail.com. 
study reported that though $h r g A$ was more prevalent among the Western countries than in Asian, its prevalence was more among gastric cancer patients in Asians compared to those with benign disease. The data also suggested that the hrgA occurred more among cagA+ve $H$. pylori strains than those lacking cagA. These results prompted us to evaluate the prevalence of this virulence determinant among the strains isolated from the South Indian population and evaluate the presence of $h r g A$ as a surrogate marker of overt gastrointestinal disorders.

\section{Experimental procedure}

We studied $H$. pylori strains from 56 dyspeptic patients (males: 32; females: 24; age range: 20-65 years) undergoinggastroscopy in the Department of Gastroenterology, Deccan College of Medical Sciences and Allied Hospitals, Hyderabad, India, for the evaluation of upper gastrointestinal symptoms. The Institutional Ethical Committee (IEC) of the hospital approved the study protocol. A total of four gastric biopsy specimens (two from the antrum and two from the corpus) were collected from each patient after taking informed consent from the subjects to take part in the study. One antral biopsy collected in brucella broth supplemented with $2 \%$ fetal calf serum (FCS) was used for culturing $H$. pylori, one corpus biopsy for histological lesions and the remaining two biopsy one each from the antrum and corpus was collected in phosphate buffered saline for the DNA analysis.

\section{Bacterial strains and growth conditions}

The collected biopsy specimens were transported to the laboratory, the specimens were best processed within 1 hour, if delayed the specimen was preserved at $4^{\circ} \mathrm{C}$ for $4-24$ hours. The biopsy was inoculated onto the chocolate brucella agar medium (Difco Laboratories, Detroit, USA) supplemented with 7\% sheep blood and antibiotics vancomycin $(6 \mathrm{mg} / \mathrm{mL})$, amphotericin-B $(2 \mathrm{mg} / \mathrm{mL})$ and polymixin-B $(2500$ units $/ \mathrm{mL})$. The plates were incubated in a microaerobic conditions at $37^{\circ} \mathrm{C}$ for $3-5$ days with 90\%-100\% humidity. Then the plates were examined after 72 hours for $H$. pylori.

The isolated colonies of $H$. pylori were again sub cultured in solid media. Rapid urease method (RUT) a touch cytology method was also done by inoculating few colonies into $250 \mu \mathrm{L}$ urea broth comprising phenol red indicator. The presence of urease activity by a rapid change in color from yellow to pink indicated active $H$. pylori. The culture was considered to be positive for $H$. pylori by observing small, translucent, tiny colonies, which on staining gave Gram-negative staining.

\section{DNA extraction and PCR amplification}

Genomic DNA isolation from 36 pure $H$. pylori cultures and 56 biopsy samples was done using a standard protocol described previously ${ }^{(8)}$. The isolated DNA was then amplified for the presence of target genes viz., cagA, hrgA and hpyIIIR of $H$. pylori using specific oligonucleotide primers and PCR conditions listed in Tables 1 and 2. The products of amplification were subsequently electrophoresed in $1.5 \%$ agarose gel stained with ethidium bromide to visualize the presence of amplified
TABLE1. List of oligonucleotide primers used during the study

\begin{tabular}{lcccc}
\hline $\begin{array}{l}\text { Target } \\
\text { gene(s) }\end{array}$ & Primer pairs & Sequence(5'-3') & $\begin{array}{c}\text { Amplicon } \\
\text { size (bp) }\end{array}$ & Reference \\
\hline \multirow{2}{*}{ rRNA 165 } & $\begin{array}{c}\text { 16SrRNA-F } \\
\text { 16SrRNA-R }\end{array}$ & $\begin{array}{c}\text { TAAGAGTACAGCCTATGTCC } \\
\text { TCCACGCTTTAAGCGCAAT }\end{array}$ & 534 & 13 \\
cagA & cagA-F & GATAACAGGCAAGCTTTTGA & 499 & This study \\
& cagA-R & CTGCAAAAGATTGTTTGGCA & & \\
hrgA & hrgA-F & TCTCGTGAAAGAGAATTCC & 594 & 1 \\
& hrgA-R & TAAGTGTGGGTATATCAATC & & \\
hpyIIIR & hpyIIIR-F & CTCATTGCTGTGAGGGAT & & \\
& hpyIIIR-R & TCTTGATAGGATCTTGCG & 420 & 1 \\
\hline
\end{tabular}

TABLE 2. Amplification conditions used for the PCR in the present study

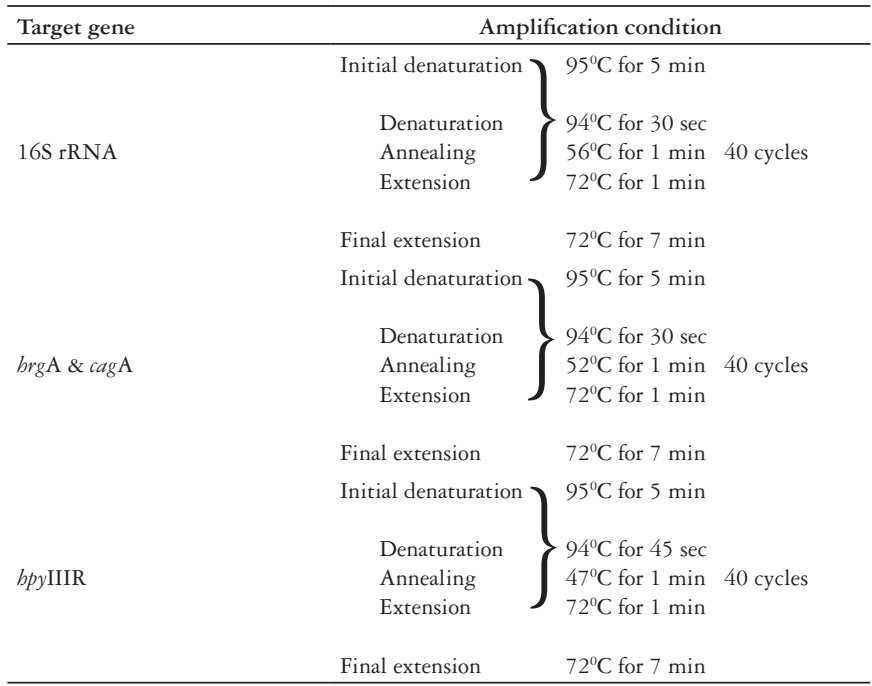

TABLE 3. Comparison of the cagA and hrgA status in $H$. pylori positive subjects

\begin{tabular}{|c|c|c|c|}
\hline S. No & Clinical status (n) & cagA status (\%) & hrgA status $(\%)$ \\
\hline 1 & Prepyloric ulcer (14) & $14(100 \%)$ & $14(100 \%)$ \\
\hline 2 & Duodenal ulcer (15) & $11(73.3 \%)$ & $15(100 \%)$ \\
\hline 3 & Gastric adenocarcinoma (14) & $14(100 \%)$ & $14(100 \%)$ \\
\hline \multirow[t]{2}{*}{4} & NUD (8) & $6(75 \%)$ & $8(100 \%)$ \\
\hline & Total (51) & $45(88.23 \%)$ & $51(100 \%)$ \\
\hline
\end{tabular}

genes. All the photographic registries were performed using a bio-rad gel documentation system.

\section{Sequencing of $\boldsymbol{h r g A}$ gene of $\boldsymbol{H}$. pylori}

Following amplification using $h r g A \mathrm{~F}$ and $h r g A \mathrm{R}$ primers, the amplimers were sequenced directly after purification with the QIAquick gel extraction kit (Qiagen) using the big dye terminator v3.1 cycle sequencing kit and injected to an ABI $3730 x \mathrm{l}$ Genetic Analyzer (Applied Biosystems, Germany).

\section{Histpathological analysis}

Histopathological analysis was mainly performed to detect the presence of H. pylori and also to ascertain the presence 
of significant preneoplastic and neoplastic lesions. Briefly, two sections $(4 \mu \mathrm{M})$ were cut from each block: one section was stained with a modified Giemsa stain, and the other section was stained with hematoxylin-eosin (H-E) to assess the presence of intestinal metaplasia and dysplasia. A single pathologist (Z. A.) who was blinded to the patient's clinical conditions evaluated all the histologic sections. Grading of the histological lesions was done according to the updated Sydney system of classification ${ }^{(3)}$.

\section{Statistical analysis}

The data obtained was evaluated using Student Chi $\left(\chi^{2}\right)$ square test and probability values less than $5 \%(P<0.05)$ was considered statistically significant.

\section{RESULTS}

Out of 56 patients enrolled for the study, we categorized the patients according to their disease status (prepyloric ulcer-14, DU-18, non-ulcer dyspepsia-10, and gastric adenocarcinoma14). H. pylori positivity was found in $36(64.28 \%)$ by culture, 44 (78.57\%) by RUT, $28(50 \%)$ by histopathology, and $51(91.07 \%)$ by biopsy DNA amplification.

\section{Status of hrgA, wA and hpyllIR gene locus}

Of the 56 genomic DNA isolated (36 cultures and 51 biopsy samples), hrgA gene amplification was seen in all the samples screened giving a product size of 594bp. Besides this, the cagA gene was found in all $(100 \%)$ the patients with pre-pyloric ulcers and gastric adenocarcinoma but only in $11(61 \%)$ with DU and $6(60 \%)$ with non ulcer dyspepsia (NUD), respectively. However, among the remaining 11 subjects with DU and NUD that did not amplify for the cagA gene, $h r g A$ amplified giving the expected product (Figure 1 and Table 3). The prevalence of hrgA was then compared

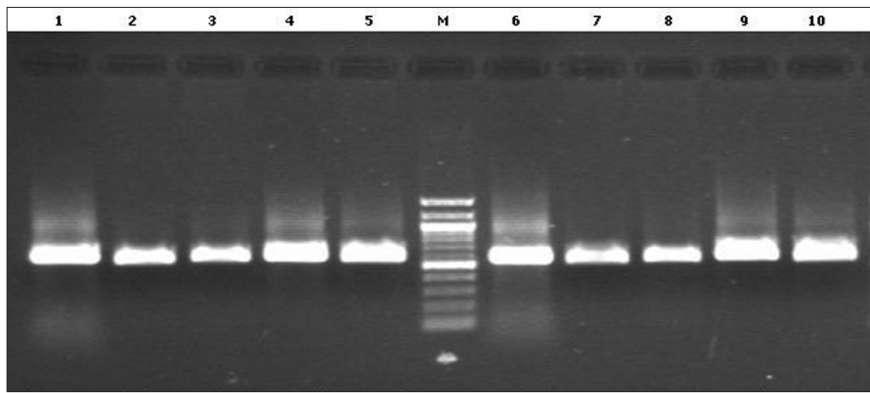

Lanes $1-10 \mathrm{H}$. pylori DNA from various patients with different gastric diseases

Lane M-100bp Molecular weight DNA marker (New England Biolabs)

FIGURE 1. Gel picture showing amplification of $\operatorname{hrg} A$ gene of Helicobacter pylori from various subjects

with the strain's cagA status, and clinical manifestations and also amplification for assessing the status of hpyIIIR gene locus PCR were performed in all the reported strains and was found to be negative except for the ATCC strain 26695. (Figure 2) All the 56 strains were found to lack the hpyIIIR locus and positive for $h r g A$ gene. Samples were amplified

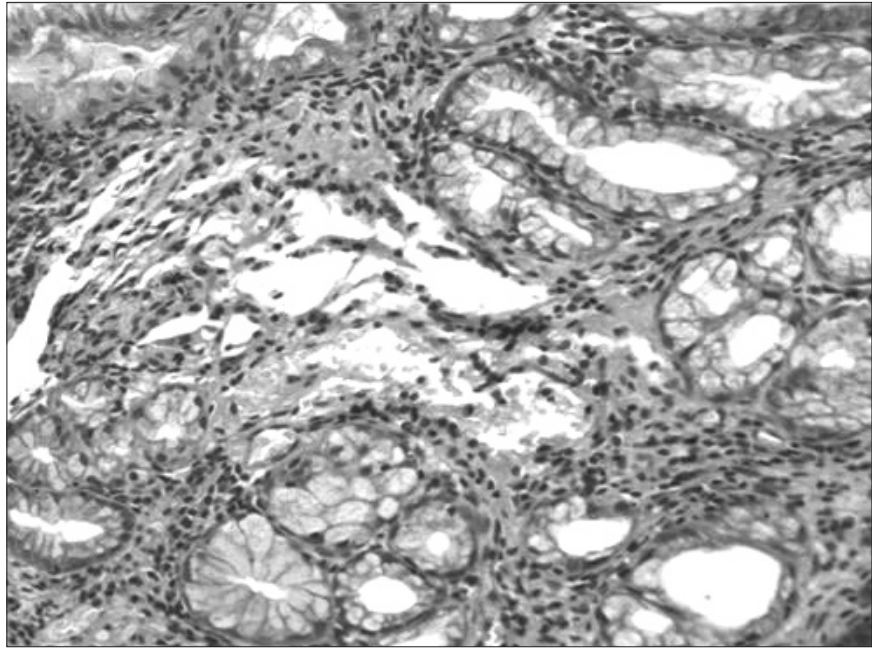

FIGURE 2. Corpus biopsy showing focal intestinal metaplasia with mild dysplasia

twice to confirm the presence of $h r g A$ gene and absence of hpyIIIR locus. No mixed genotypes of $h p y$ IIIR/hrgA were found in this study.

\section{Histological assessment}

Analysis of the sections from each biopsy from various patients showed chronic gastritis grade II among 10 (66.67\%) subjects with DU, 8 (57.14\%) with pre-pyloric ulcer, 3 (37.5\%) with NUD, whereas chronic grade III gastritis with atrophic gastritis was seen in $2(13.33 \%)$ with DU, $5(35.71 \%)$ with pre-pyloric ulcers. H-E staining showed mild intestinal metaplasia (IM) in one $(6.67 \%)$ subject with DU and one (7.14\%) with pre-pyloric ulcer. Among 14 gastric carcinoma subjects, high grade dysplasia was seen in $8(57.14 \%)$ and low grade dysplasia in $3(21.42 \%)$ subjects, the remaining 3 (21.42\%) subjects showed foci of chronic atrophic gastritis with moderate IM (Figures 3 and 4).

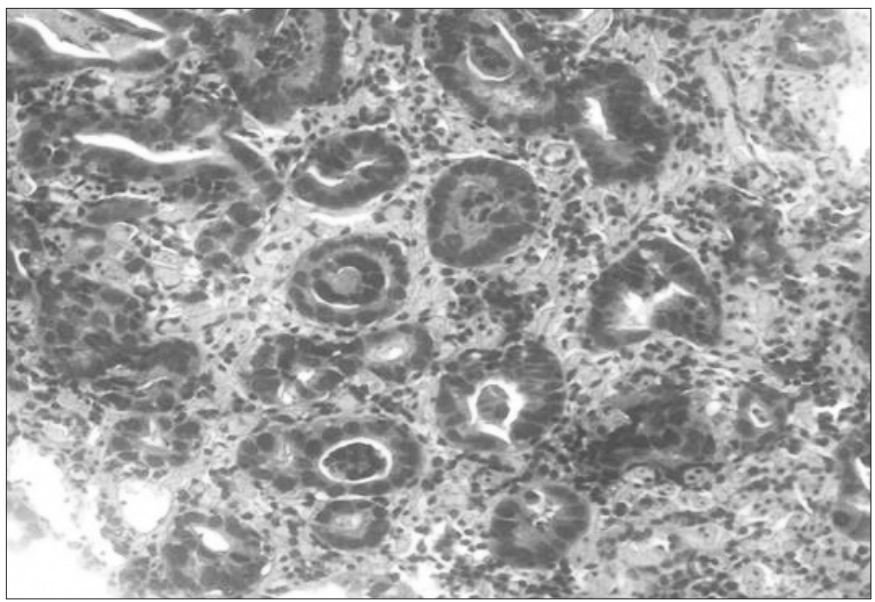

FIGURE 3. Invasion of stroma, dysplasia associated with invasive intestinal type cancer 


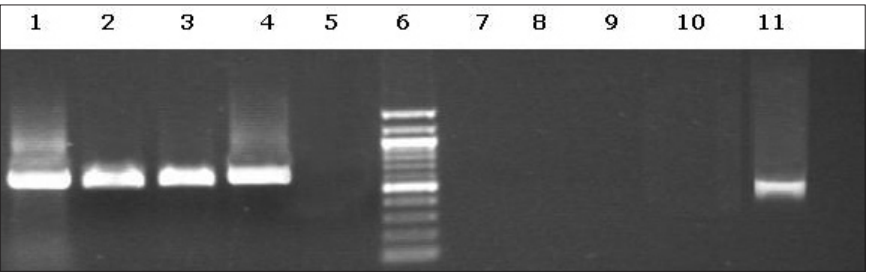

Lane $1-4$ representing hrgA gene amplification $(596 \mathrm{bp}$ ) of $\mathrm{H}$. pylori strain Lane 5 \& 11 indicates control (ATCC 26695 strain) used for hrgA amplification \& hpylllR locus amplification Lane $6100 \mathrm{bp}$ Molecular marker (New England Biolabs) Lane 7.10 represents hpyllliR amplification in hrgA amplified strains.

FIGURE 4. Gel photograph showing amplification of the hgrA and hpyIIIR Status in $H$. pylori strains

\section{Sequence analysis}

Sequences obtained were compared using BLAST ${ }^{\mathrm{n}}$ with the NCBI database. Sequencing analysis showed the presence of hrgA gene of $H$. pylori with a homology of $99 \%$.

\section{DISCUSSION}

The present study evaluated the presence of Helicobacter pylori restriction endonuclease-replacing gene ( $h r g A)$ among subjects with various gastric disorders. The results of this study showed the presence of $h r g A$ gene in all the $51(100 \%) \mathrm{H}$. pylori strains isolated from each subjects with different clinical presentations.

Even though number of bacterial virulence determinants such as the genes of the cag-pathogenicity island, vacA, ice $\mathrm{A}$, and $b a b \mathrm{~A}$, have been extensively studied in the past (in association with) the clinical status in various geographical regions. No significant association could be established with the presence of any of these genes with respect to the clinical outcome, the main reason being the highly plastic genome of H. pylori ${ }^{(6,12,15)}$, therefore in a continued pursuit to identify novel bacterial markers of $H$. pylori, which could serve as a surrogate marker of disease progression, ANDO et al. ${ }^{(1)}$ reported the presence of $h r g A$ to be high among patients with gastric cancer of the Asian population than those with non-cancerous or benign form of disease. However the present study could not find any such specific association of this gene with any of the disease conditions and found that the hrgA gene was present in all the subjects included in the study irrespective of their disease status. Further this study also found that the prevalence was not dependent on the presence of the cagA gene as it was evenly distributed among the patients with cagA positive and cagA negative $H$. pylori strains.

As evident from the results, we could not find any significant difference in the histological pattern among the subjects infected with cagA+ve/hrgA+ve H. pylori and those with $\operatorname{cagA}$-ve/hrgA+ve. These findings suggest that development of overt disease such as ulceration or gastric carcinoma cannot be predicted based on the presence or absence of a one or two bacterial virulence factors. Rather development of severe form of disease is a result of complex molecular interactions between the host and the bacterial factors over a period of time that causes significant damage to the host. In addition, the site of the stomach where $H$. pylori colonizes also has an important bearing on the predisposition to develop prepyloric ulcer, DU and gastric cancer. Further, the environmental factors also play major role in disease manifestation besides the host and bacterial factors. This could have been one of the main reasons in ANDO et al. ${ }^{(1)}$ study that could not establish a correlation between $h r g A$ gene and gastric cancer patients of the Western countries whereas the same was possible among the Asian gastric cancer patients.

The results obtained in the present study are in contrast to those obtained by ANDO et al. ${ }^{(1)}$ thereby suggesting that, though presence of $h r g A$ had a higher predictive value for gastric carcinoma, our study however, could not hint at any such correlations, as $\mathrm{hrgA}$ gene was found to be present unequivocally in all the strains screened from various disease pathologies. The exploration for reasons responsible for these varied results warrants further investigations on large cohort population from different geographic areas. Besides this, an in depth molecular profile of the R-M systems and especially the functional role of $h r g A$ gene would further be helpful to delineate the direct/ indirect role played by this gene in gastric carcinogenesis.

In conclusion, hrgA gene of $H$. pylori may not be used as a ideal surrogate marker for identifying individuals at higher risk of overt form of gastro-intestinal disorders among the South Indian population.

\section{ACKNOWLEDGEMENTS}

We are grateful to Dr. Rekha for her continued interest during the course of the study and also to my mentor Dr. Aleem Ahmed Khan for his support and patronage. We are also very thankful to G. Sivaram, Shakeel Ahmed, Santhosh Kumar. B, Tatipalli Neeraj, Zakia Abid for their technical support for the study. 
G M, Tiwari SK, SHAMA V, Habeeb MA, Khan AA, CM H. Associação entre o hrgA (Helicobacter pylori restriction endonuclease-replacing gene) com as principais doença gastrointestinais. Arq Gastroenterol. 2008;45(3):225-9.

RESUMO - Racional e Objetivos - O Helicobacter pylori tem sido incriminado como causador de vários distúrbios digestivos, incluindo o adenocarcinoma gástrico. Diversos genes patogênicos (os genes do cag-PAI, vacA, iceA e babA), em combinação ou independentes, têm sido reportados como fatores de aumento de risco para ulceração/carcinoma gástrico, tendo o gene cagA forte valor preditivo. A procura da identificação de novos genes que possam vir a ser marcadores da progressão da doença levaram à descoberta do gene hrgA. Métodos - Cinqüenta e seis amostras de H. pylori provenientes de pacientes com diversas afecções gástricas foram examinadas para caracterizar a presença do hrgA juntamente ao cagA, usando iniciadores específicos da reação de cadeia da polimerase. Após amplificação, os produtos amplificados pela PCR foram seqüenciados para a identificação de variações específicas nas seqüências do H. pylori isolado de diferentes doenças gastroduodenais. A análise histopatológica foi feita para assegurar qualquer mudança significativa nos escores dos indivíduos infectados com cagA+hrgA+ e cagA-/hrgA+. Resultados - Todas as 56 amostras (100\%) foram amplificadas com iniciadores específicos para o hrgA, enquanto que $81,71 \%$ mostraram a presença do cagA. O seqüenciamento do produto amplificado pela PCR mostrou $99 \%$ de homologia. A histologia entre os grupos cagA $+/ \mathrm{hrgA}+$ e cagA-/hrgA + não mostrou nenhuma diferença significante. Conclusão - O gene hrgA do $H$. pylori não é o marcador ideal para identificar indivíduos com alto risco de desenvolvimento de doenças gastrointestinais como a neoplasia de estômago.

DESCRITORES - Helicobacter pylori. Neoplasias gástricas. Adenocarcinoma. Proteínas de bactérias. Reação em cadeia da polimerase.

\section{REFERENCES}

1. Ando T, Wassenaar TM, Peek RM Jr, Aras RA, Tschumi AI, van Doom LJ, Kusugami $\mathrm{K}$, Blaser MJ. A Helicobacter pylori restriction endonuclease-replacing gene, $\mathrm{hrg} \mathrm{A}$ is associated with gastric cancer in Asian strains. Cancer Res. 2002;62:2385-9.

2. Aspholm-Hurtig M, Dailide G, Lahmann M, Kalia A, Ilver D, Roche N, Vikstrom S, Sjostrom R, Linden S, Backstrom A, Lundberg C, Arnqvist A, Mahdavi J, Nilsson UJ, Velapatino B, Gilman RH, Gerhard M, Alarcon T, Lopez-Brea M, Nakazawa T, Fox JG, Correa P, Dominguez-Bello MG, Perez-Perez GI, Blaser MJ, Normark S, Carlstedt I, Oscarson S, Teneberg S, Berg DE, Boren T. Functional adaptation of BabA, the $H$. pylori $\mathrm{ABO}$ blood group antigen binding adhesin. Science. 2004;305:519-22.

3. Dixon MF, Genta RM, Yardley JH, Correa P. Classification and grading of gastritis. The updated Sydney System. International Workshop on the Histopathology of Gastritis, Houston, 1994. Am J Surg Pathol. 1996;20:1161-81.

4. IARC (International Agency for Research on Cancer) Working Group on the Evaluation of Carcinogenic Risks to Humans. Helicobacter pylori. In: Schistosomes, liver flukes and Helicobacter pylori / World Health Organization, International Agency for Research on Cancer. Geneva: The Agency: Secretariat of the World Health Organization [distributor]; 1994. p.177-240. (IARC monographs on the evaluation of the carcinogenic risk of chemicals to humans, v. 61).

5. Israel DA, Salama N, Krishna U, Rieger UM, Atherton JC, Falkow S, Peek RM Jr. 2001. Helicobacter pylori genetic diversity within the gastric niche of a single human host. Proc Natl Acad Sci U S A. 2001;98:14625-30.

6. Ladeira MS, Rodrigues MA, Salvadori V, Neto PP, Achilles P, Lerco MM, Rodrigues PA, Goncalves I Jr, Queiroz DM, Freire-Maia DV. Relationships between $\operatorname{cagA}$, vacA, and iceA genotypes of Helicobacter pylori and DNA damage in the gastric mucosa. Environ Mol Mutagen. 2004;44:91-8.
7. Maeda S, Ogura K, Yoshida H, Kanai F, Ikenoue T, Kato N, Shiratori Y, Omata, M. Major virulence factors, vacA and cagA, are commonly positive in Helicobacter pylori isolates in Japan. Gut. 1998;42:338-43.

8. Mapstone NP. The detection of Helicobacter pylori by the polymerase chain reaction. In: Clayton CL, Mobley HLT, editors. Methods in molecular medicine: Helicobacter pylori protocols. Totowa, NJ: Humana Press; 1997. p.31-6.

9. Parkin DM, Bray FI, Devesa SS. Cancer burden in the year 2000. The global picture. Eur J Cancer. 2001;37(Suppl 8):s4-s66.

10. Peek RM Jr. Events at the host-microbial interface of the gastrointestinal tract IV. The pathogenesis of Helicobacter pylori persistence. Am J Physiol Gastrointest Liver Physiol. 2005;289:g8--g12.

11. Pinto-Santini D, Salama NR. The biology of Helicobacter pylori infection, a major risk factor for gastric adenocarcinoma. Cancer. Epidemiol Biomarkers Prev. 2005; $14: 1853-8$.

12. Sadakane Y, Kusaba K, Nagasawa Z, Tanabe I, Kuroki S, Tadano J. Prevalence and genetic diversity of $\operatorname{cag} \mathrm{D}, \operatorname{cag\mathrm {E}}$, and $v a c \mathrm{~A}$ in Helicobacter pylori strains isolated from Japanese patients. Scand J Gastroenterol. 1999;34:981-6.

13. Tiwari SK, Khan AA, Khan SA, Ali M, Habeeb A, Kauser F, Hussain MA, Ahmed N, Habibullah CM. PCR based analysis of the cag-PAI of Helicobacter pylori from saliva: an approach for rapid molecular genotyping in correlation with disease status. J Gastroenterol Hepatol. 2005;20:1560-8.

14. Vieth M, Stolte M. Elevated risk for gastric adenocarcinoma can be predicted from histomorphology. World J Gastroenterol. 2006;12:6109-14.

15. Zheng PY, Hua J, Yeoh KG, Ho B. Association of peptic ulcer with increased expression of Lewis antigens but not cagA, ice A, and vacA in Helicobacter pylori isolates in an Asian population. Gut. 2000;47:18-22.

Recebido em 13/12/2007. Aprovado em 1/2/2008 